\title{
Trust Beneficial Right Asset Securitization and High Financing Costs
}

\author{
Huanhuan Ruan
}

No. 3 Shangyuancun, Beijing Jiaotong University, Haidian District, Beijing 100044, China

ruan_hh@126.com

Keywords: trust beneficial right; asset securitization; financing cost; liquidity

Abstract. The trust beneficial right asset securitization has general advantage of asset securitization that it can reduce financing costs. But in China, financing by issuing trust beneficial right securitizations does not have an advantage. There are many factors that can lead to this phenomenon. In this paper, we analyzed the special asset management plan of the trust beneficial right securitization that sponsored by Haiyin co., LTD. We found that liquidity of the securitizations is the main factor influenced by recognition, the terms of the design, market system and laws. Liquidity risk requires compensation, so financing by issuing trust beneficial right securitizations can't effectively reduce the financing costs.

\section{Introduction}

Trust beneficial right asset securitization is a kind of enterprise asset securitization, whose underlying asset is trust beneficial right. The special asset management plan of the trust beneficial right asset securitization that sponsored by Haiyin co., LTD (we call it Haiyin Project) in august, 2014 is the first project of trust beneficial right securitization. It means that enterprises can finance by the securitization of the trust beneficial right. The trust beneficial right asset securitization has the general advantages of asset securitization that it can reduce financing costs. But in fact, the yield paid by Haiyin Project is overtopped the bonds that have the same maturity and qualification as the Haiyin Project. It conflicts with theoretical advantage that asset securitization can reduce financing costs. This paper embarks from the financing cost problem of Haiyin project, and then analyzes the factors that influence the financing costs of the trust beneficial right asset securitization.

\section{Background on Trust Beneficial Right Securitizations}

2.1. What is Asset Securitization and Asset-backed security? Asset Securitization converts assets into securities those available for sale. Its underlying assets are cash flow which is illiquid but stable, such as housing loans and other receivables. In an asset securitization, financing firm packages its one or more stable assets (underlying assets) and then sold to Special Purpose Vehicle (SPV) [1]. And then the SPV formulates an asset management plan. There will be a third-party rating or guarantee for the asset management plan. Asset management plan obtain financing by issuing securities (or the underlying securities).

These transactions are called "Asset-backed securities" (ABS). Outside investors buy asset-backed securities and obtain a return on investment. The SPV is "special purpose" because it typically has no activities other than the asset management plan. Theoretically, SPV isolates assets and the financing firm, so the interest or risk that belongs to asset-backed securities does not rely on the parent company's credit.

Asset securitization transactions typically are complex, and the risks and rewards of the SPV's investors and the firm differ depending on the terms of the transaction. 


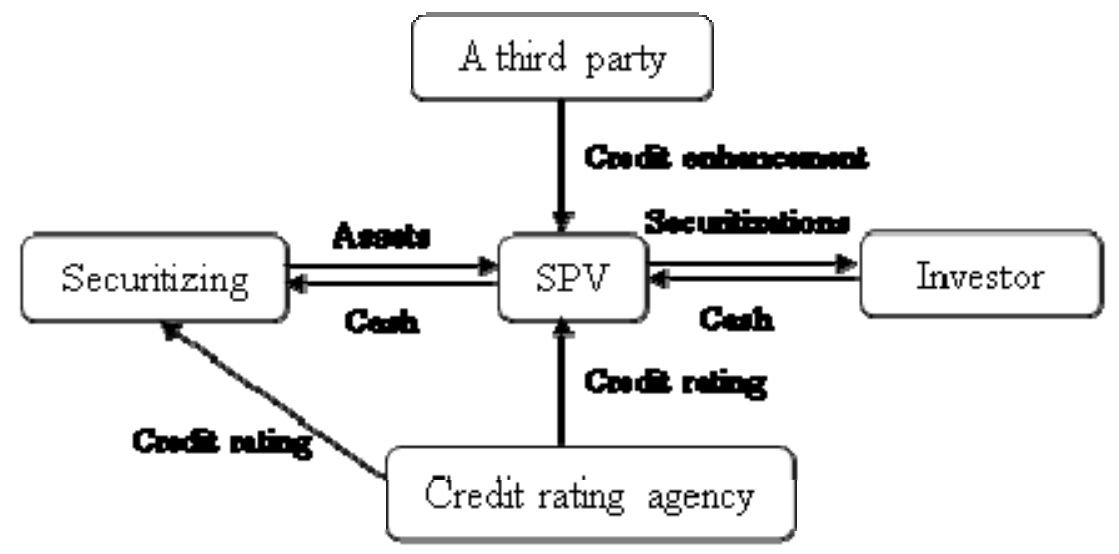

Fig 1 The tructure of asset securitization

2.2 What is Trust Beneficial Right? Trust beneficial right is that right which a person has in a contract made with another (third) person. The typical example is "if A makes a contract with B that A will pay $\mathrm{C}$ a certain sum of money, $\mathrm{B}$ has the legal interest in the contract, and $\mathrm{C}$ the beneficial interest."

The trust beneficial right has the following features. First, it has the nature both of real right and creditor's right. It means that the creditor enjoys the rights and interests created by the trust, so it must be property rights. Second, the trust beneficial right can be transferred. This kind of right is implemented by transferring property. So before designing trust beneficial right asset securitization, the securitizing company must ensure that the property meets the conditions of negotiable. The beneficiary is the person who obtains the trust benefits, also one of the relationships of the parties.

\section{Data Description}

The data of the yield of Haiyin Project comes from the Instruction of the Beneficial Trust Assets Management Plan of Haiyin co., LTD. This paper adopts the yields of five classes (1-5 years).

The data of central bank lending rates, bond yields and corporate bond yields comes from The Central Treasury Securities Registration and Settlement co., LTD. This paper adopts one-year, one-to-three-year and three-to-five-year Benchmark loan rates; one-year, three-year and five-year yields of Treasury bond; one-year, three-year and five-year yields of AA-company.

\section{Case Analysis}

Trust beneficial right asset securitization is one type of the enterprise asset securitization. One of its core mechanisms is the bankruptcy isolation mechanism. Underlying assets will be spun off from the enterprise's assets, and are not affected by the enterprise risk. The underlying assets are no longer associated with other assets of the company, and their risks are independent of the company's. Moreover, they have relatively stable cash flow. Finally, there are rating agency rating for securities and external shareholders guaranteeing for securities. Thus theoretically, underlying assets have high quality and the securitizations can be widely accepted. If the company finance by issuing securitizations, there is an advantage to reduce the cost. But the reality is not in conformity with the theory. We can have a better understanding on this problem by analyzing the financing costs of Haiyin Project.

In recent years, the growth of operating income and net income of Haiyin has been slow down. And on the other hand, the company has increased the reservation in the real estate market [2]. But the company cannot provide enough financial support. So it must seek to other financing channels. In addition to traditional channels, Haiyin raise money by issuing asset securitizations for the first time. It mortgages its rent usufruct, financing by issuing the trust beneficial right securitizations. 
In September 2014, the one-year benchmark loan rate is 6\%, and one to three benchmark loan rate is $6.15 \%$, and three to five benchmark loan rate is $6.40 \%$, and that of more than 5 years is $6.55 \%$. The one-year yield of Treasury bond is 3.74\%, three-year Treasury bond yield is $3.81 \%$, and five-year Treasury bond yield is $3.91 \%$. According to the data, the yield of the bonds that have the same maturity and qualification as the Haiyin Project is less than that of Haiyin Project. The one-year corporate bond yields of AA-company is $5.37 \%$, three-year corporate bond yields of AA-company is $5.79 \%$, and five-year corporate bond yields of AA-company is 6.33\%. But for the securitizations of Haiyin Project, The expected return of 1 to 5 years ranges from 6.8\% to 8.38\%. Expected return that Haiyin paid to investors is higher than that of the bonds that have the same maturity and qualification.

Table 1 the comparison to yields

\begin{tabular}{ccccc}
\hline & $\begin{array}{c}\text { Haiyin Project } \\
{[\%]}\end{array}$ & $\begin{array}{c}\text { Benchmark } \\
\text { loan rate [\%] }\end{array}$ & $\begin{array}{c}\text { Treasury bond } \\
\text { yield [\%] }\end{array}$ & $\begin{array}{c}\text { Corporate bond } \\
\text { yields of } \\
\text { AA-company } \\
{[\%]}\end{array}$ \\
\hline One-year & 6.8 & 6 & 3.74 & 5.37 \\
Two-year & 7.45 & 6.15 & -- & -- \\
Three-year & 7.8 & & 3.81 & 5.79 \\
Four-year & 8.05 & 6.4 & -- & -- \\
Five-year & 8.38 & & 3.91 & 6.33 \\
\hline
\end{tabular}

Apart from Haiyin Project, the yield of Project of Zhongxin-Maoyong ranges from 4.9-6.0\% while one-to-five-year benchmark loan rate is $4.75 \%$ and that of more than five years is $4.9 \%$, The one-year corporate bond yields of AA-company is 3.83\%, three-year corporate bond yields of AA-company is $4.89 \%$, and five-year corporate bond yields of AA-company is $4.89 \%$.

\section{Analysis on Influencing Factors}

5.1 Recognition to Trust Beneficial Right Securitization. Asset securitization sprung up in 2005 in China. It has been developing for only 10 years, which is shorter than some developed market, such as American that has been developing for 30 years. In developed market, underlying assets can be car loans, credit card receivables, consumer installment, rent, copyright royalties, highway tolls, etc. Japan, South Korea and some of Asian countries developed asset securitization after the Asian financial crisis in 1997. It has been 20 years so far. American, European, Japanese, South Korean markets are more developed than that of our country, and system is more complete. Investors of these countries can quickly accept new ways of financing.

Trust beneficial right securitization sprung up in 2014 in China. Investors have not fully accepted the new way of financing so far. If the trading volume is too small, there will be liquidity risk. Liquidity risk requires compensation.

5.2 Securities Defects in Product Design. To attract investors, the securitizing company ought to create a perfect product design. Trust beneficial right securitization is still in early stage, there are some defects in product design, which prompted investors to question the financing function of trust beneficial right securitization. The main problem is that whether company's asset is a true sale or collateral? Consistent with this lack of clarity, there is an ongoing debate regarding the appropriate accounting treatment for asset securitizations. Accounting standards relating to asset securitizations specify conditions that must be met for a securitization transaction to be treated as a sale. Under the current accounting rules, for a securitization to receive sale treatment, the risk of the assets must be completely transferred to the SPE. If the risk transfer is incomplete, i.e., some or all of the risk resides with the securitizing firm, which means the securitization is treated as secured borrowing.

In China, initial SPE can only be special asset management plan that sponsored by security companies. Such a plan is not a legal entity so it cannot truly sale the asset to other instructions. So the risk of the asset resides with the securitizing firm, which disappoints the investors. Although there are 
structure "special asset management plan plus trust" (trust is a legal entity and it can truly sale its asset), some projects still couldn't realize the bankruptcy isolation and true sale of its assets.

The underlying asset of Haiyin Project is the usufruct of commercial real estate. Actually, the ownership of the asset doesn't belong to Haiyin, and Haiyin Project couldn't be treated as a sale. Such a defect has weakened the investors willing to invest.

5.3 Imperfection in Market System and Law. Securities and capital can freely flow in the market when the market is an efficient market [3]. In China, corporate asset-backed securities are supervised by the CSRC, circulating in block trading system in Stock Exchange, while credit asset backed securities are supervised by CBRC, circulating in interbank bond market. The two systems are isolated. If investors want to make asset-backed securities investment in the two different markets, they must open two different securities accounts. Securities and capital cannot freely flow in the market.

In China, there are defects in the market system and laws. Market fragmentation weakens the free circulation of securities.

5.4 Other Factors that Affect the Securities Credit Rating. Theoretically, underlying assets are isolated to other assets of the company. Moreover, there are external shareholders guaranteeing for securities. So the securitizations issued by SPE have a high credit rating, and the circulation of the securitizations will be improved with it. But we couldn't make it come true in reality. Maybe there is a problem in the process of information transfer. For instance, the information disclosure of securitizing company is not comprehensive, or the rating agency is not professional for the securitization project.

\section{Conclusion}

Trust beneficial right asset securitization sprung up in 2014 in China. It's an innovation, but has been questioned. Moreover, there are some defects in product design, which prompted investors to question the financing function of trust beneficial right asset securitization. Besides, there are defects in the market system and laws. The securities and capital of different bond markets couldn't freely flow. Finally, information asymmetry makes the situation worse.

The liquidity shortage of securities makes the holders require a higher yield to compensate losses later they may suffer. At present, the trading volume and turnover rate of asset-backed securities are far less than bonds and the corporate bonds that have the same maturity and qualification. So in China, the trust beneficial right asset securitization is a way of financing, however, the advantage of it that it can lower financing costs haven’t been brought into play.

\section{References}

[1] Barth, Mary E. "Asset Securitizations and Credit Risk." Accounting Review 87.2(2011):423-448.

[2] WEI Pei, Research on financing models of Commercial Real Estate Asset Securitization--Case study on trust beneficiary special asset management plan of Haiyin co., LTD. Diss. JINAN University (2015).

[3] SU Xueling. Cause Analysis and Countermeasures on the illiquidity of Asset-backed securities. Diss. University of Science and Technology of China (2008). 